\title{
The occurrence of germline BRCA1 and BRCA2 sequence alterations in Slovenian population
}

\author{
Vida Stegel', Mateja Krajc ${ }^{2}$, Janez Žgajnar ${ }^{3}$, Erik Teugels ${ }^{4}$, Jacques De Grève ${ }^{4}$, Marko Hočevar ${ }^{3}$, Srdjan Novakovićc ${ }^{*}$
}

\begin{abstract}
Background: The BRCA1 and BRCA2 mutation spectrum and mutation detection rates according to different family histories were investigated in 521 subjects from 322 unrelated Slovenian cancer families with breast and/or ovarian cancer.

Methods: The BRCA1 and BRCA2 genes were screened using DGGE, PTT, HRM, MLPA and direct sequencing.

Results: Eighteen different mutations were found in BRCA1 and 13 in BRCA2 gene. Mutations in one or other gene were found in 96 unrelated families. The mutation detection rates were the highest in the families with at least one breast and at least one ovarian cancer - $42 \%$ for BRCA1 and $8 \%$ for BRCA2. The mutation detection rate observed in the families with at least two breast cancers with disease onset before the age of 50 years and no ovarian cancer was $23 \%$ for BRCA1 and $13 \%$ for BRCA2. The mutation detection rate in the families with at least two breast cancers and only one with the disease onset before the age of 50 years was $11 \%$ for BRCA1 and $8 \%$ for $B R C A 2$. In the families with at least two breast cancers, all of them with disease onset over the age of 50 years, the detection rate was $5 \%$ for BRCA2 and 0\% for BRCA1.

Conclusion: Among the mutations detected in Slovenian population, 5 mutations in BRCA1 and 4 mutations in BRCA2 have not been described in other populations until now. The most frequent mutations in our population were c.181T > G, c.1687C > T, c.5266dupC and c.844_850dupTCATTAC in BRCA1 gene and c.7806-2A > G, c.5291C > G and c.3978insTGCT in BRCA2 gene (detected in 69\% of BRCA1 and BRCA2 positive families).
\end{abstract}

\section{Background}

Breast cancer represents $20.7 \%$ of all malignancies in females and is the most frequent type of cancer in the Slovenian female population. In 2007, 1147 new breast cancer cases were registered in Slovenia. The incidence rate among Slovenian women was 112/100000 and is slowly increasing. Breast and ovarian cancers together represent as much as $23.9 \%$ of all cancers in Slovenian females [1]. The majority of these two types of cancer are sporadic and only a small proportion $(5 \%-10 \%)$ is known to be caused by dominantly inherited susceptibility genes [2]. The BRCA1 and BRCA2 genes were found to be mutated in a large number of families with multiple cases of an early onset of breast and ovarian cancer [3-6]. Mutations in BRCA1 and BRCA2 are highly penetrant and confer an increased risk of breast and ovarian

\footnotetext{
*Correspondence: snovakovic@onko-i.si

'Department of Molecular Diagnostics, Institute of Oncology Ljubljana,

Zaloska 2, 1000 Ljubljana, Slovenia

Full list of author information is available at the end of the article
}

cancer in carriers [7-9]. The cumulative breast cancer risk for $B R C A 1$ and $B R C A 2$ mutation carriers at the age of 70 was, in different studies, reported to be between $36 \%$ and up to $71 \%[10,11]$. The studies of the Breast Cancer Linkage consortium based on the families with four or more cancer cases reported an approximate breast cancer risk of $80 \%$ at the age of 70 for mutation carriers $[7,8,12]$. The reported cumulative risk for ovarian cancer in BRCA1 and BRCA2 carriers at the age of 70 was $39 \%$ to $60 \%$ and $22 \%$ to $27 \%$, respectively $[8,13,14]$.

Up to now, several comprehensive studies performed throughout Europe determined the mutation profiles of $B R C A 1$ and BRCA2 in families with history of breast and ovarian cancer. One of the largest studies carried out by a German consortium included 989 unrelated families with a history of breast and ovarian cancer who were screened for mutations in BRCA1 and BRCA2. The frequency of detected mutations in this study varied from $14 \%$ to $50 \%$ according to different family histories [15].
C Biomed Central

() 2011 Stegel et al; licensee BioMed Central Ltd. This is an Open Access article distributed under the terms of the Creative Commons Attribution License (http://creativecommons.org/licenses/by/2.0), which permits unrestricted use, distribution, and reproduction in any medium, provided the original work is properly cited. 
Another large study included 1010 unrelated families from the Czech Republic with an overall mutation detection rate of $29 \%$ for $B R C A 1$ and $B R C A 2$ [16]. A similar study was performed in the Dutch population which included 517 unrelated families, where an overall mutation detection of 23\% was reported [17]. In French, Swedish and Finnish populations, 100 to 200 families were screened for BRCA1 or BRCA2 mutations [18-20]. The mutation detection rates in these studies varied from 10 to $25 \%$. A higher mutation detection rate of $33 \%$ was observed in the study which included 42 Belgian families [21,22]. A comparably high overall mutation detection rate of $30 \%$ was reported also among 102 Spanish families [23]. In the Austrian population, the mutation detection rate was reported to be $20 \%$ for $B R C A 1$ among 86 breast and ovarian cancer families [24]. In Italy, several reports were published. The overall mutation detection rate for $B R C A 1$ and $B R C A 2$ in these reports varied from 8 to $37 \%$ [25-29].

Slovenia is a country located in the central European area with approximately 2 million inhabitants. Since 1999, genetic counseling and testing for hereditary breast and ovarian cancer have been offered at the Institute of Oncology Ljubljana. Until now, approximately 1100 individuals have attended genetic counseling and 521 individuals from 322 families opted for genetic testing.

With this article, we wanted to present the $B R C A 1$ and $B R C A 2$ mutation spectrum and mutation detection rates according to different family histories in Slovenian the population.

\section{Methods}

Tested individuals

521 persons from 322 Slovenian families with breast and/or ovarian cancer underwent genetic testing. When possible, the proband tested for the presence of mutation in BRCA1 and BRCA2 genes in the family was the youngest individual affected by breast or ovarian cancer. All tested individuals provided written informed consent and attended genetic counseling sessions before and after testing.

All tested individuals were classified according to their family history. The family history data were verified in the Slovenian state cancer registry established in 1950.

The enrolled families were divided into 6 different groups according to the following criteria:

Group A: Families with two or more cases of breast cancer among first-degree relatives, including at least two cases with the disease onset under the age of 50, with no ovarian cancer.

Group B: Families with one or more cases of breast and at least one ovarian cancer among first-degree relatives.
Subgroup BA - families with at least one ovarian cancer and at least two breast cancers under the age of 50 ;

Subgroup $B C$ - families with at least one ovarian cancer and at least two breast cancers, one under the age of 50 ;

Subgroup BD - Families with at least one ovarian cancer and at least two breast cancers, all beyond the age of 50 ;

Subgroup $1 B+1 O$ - Families with only one ovarian cancer and one breast cancer in the family or only one affected individual in the family, but having both types of cancer at the same time;

Subgroup more $O+1 B$ - Families with at least two ovarian cancers and only one breast cancer;

Subgroup only $O$ - Families with at least two ovarian cancers and no breast cancer;

Group C: Families with two or more cases of breast cancer among first-degree relatives, including one case diagnosed before the age of 50 and no ovarian cancer.

Group D: Families with two or more cases of breast cancer among first-degree relatives, all diagnosed beyond the age of 50 and no ovarian cancer.

Group E: Families with a single case of female breast cancer diagnosed under the age of 40 .

Group MBR: Families with a single breast cancer among first-degree relatives being the male breast cancer.

Bilateral breast cancers were counted as two independent cases of breast cancer.

Controls: The control group consisted of healthy volunteers, females aged from 50 to 69 years without any familial and personal history of breast and/or ovarian cancer who were tested for the presence of all mutations, unclassified variants (UV) and polymorphisms found in patients.

\section{Mutation screening}

The DNA was isolated from peripheral blood using the DNA blood isolation kit (Qiagen, Hilden, Germany).

Mutation screening in BRCA1 and BRCA2 genes was performed by two laboratories - the Laboratory of Molecular Oncology at the Vrije University Brussels, Belgium and the Laboratory of Molecular Diagnostics at the Institute of Oncology Ljubljana, Slovenia.

All samples were, at the beginning, tested for six most frequent mutations in the Slovenian population (c.78062A > G in BRCA2, c.5266dupC, c.1687C > T, c.191G > A, c. $181 \mathrm{~T}>\mathrm{G}, \mathrm{c} .181 \mathrm{~T}>\mathrm{A}$ in BRCA1) [30,31].

In the Laboratory of the Vrije University Brussels, screening for six most frequent mutations was done by denaturing gradient gel electrophoresis (DGGE) for 
mutations c.5266dupC, c.191G >A, c.181T > G, c.181T > $\mathrm{A}$ in $B R C A 1$ and c.7806-2A $>\mathrm{G}$ in $B R C A 2$ and by protein truncation test (PTT) for mutation c.1687C > T in $B R C A 1$. The additional screening of $B R C A 1 / 2$ was performed with PTT (screening of exon 11 in $B R C A 1$ and exons 10 and 11 in $B R C A 2$ ) and DGGE (the rest of exons of BRCA1 and BRCA2) [21].

In the Laboratory of the Institute of Oncology Ljubljana, screening for six most frequent mutations was done using fluorescent hybridization probes on Light Cycler 2.1 for c.5266dupC, c.1687C > T, c.191G > A, c.181T > G in BRCA1, high-resolution melting - HRM on Light Cycler 480 II (Roche Molecular Biochemicals, Mannheim, Germany) for c.181T > A in BRCA1 and restriction length polymorphism for c.7806-2A > G in $B R C A 2$ [30,31]. The additional screening of $B R C A 1 / 2$ was performed with DGGE.

In both laboratories, the DGGE was performed using primers designed by Ingeny and according to the manufacturer's instructions (Ingeny International BV, Goes, Netherlands).

Samples presenting migration abnormalities were further sequenced on the automated sequence analyzer ABI310 (Applied Biosystems, USA) (using the BDT v.1.1 and performing the labeling PCR reaction) according to manufacturer's instructions. The samples were screened for the presence of large deletions and duplications using the multiplex ligation-dependent probe amplification MLPA kit (MRC Holland, Amsterdam, Netherlands). For BRCA1 gene, the MLPA analysis was performed with probe set $\mathrm{P} 002$ and confirmed by probe set P087, and for BRCA2 with probe set P045-B1. The deletion breakpoints were not characterized at the sequence level.

The description of nucleotide sequence variations is in accordance with HGVS nomenclature, and in tables, also in accordance with BIC nomenclature [32,33]. According to HGVS nomenclature DNA variants are numerated according to NCBI reference sequence NM_007294.2 for BRCA1, NM_000059.3 for BRCA2. The first nucleotide of the start codon ATG is numerated as 1 . According to BIC nomenclature, DNA variants are numerated according to NCBI reference sequence HSU14680 for mRNA of BRCA1, or U43746 for mRNA of BRCA2. The first nucleotide of mRNA is numerated as 1 .

Statistical analysis was performed using the Chi-square test.

\section{Results}

The study was performed on 521 individuals from 322 Slovenian breast and/or ovarian cancer families. In 96 families, either the mutation in BRCA1 or the mutation in $B R C A 2$ was detected. The overall mutation detection rate for BRCA1 and BRCA2 genes was $29.8 \%$ (96/322). Thus, in 226 families, we found no pathogenic mutation in either of the two investigated genes.

\section{BRCA1 mutation spectrum}

In $B R C A 1,18$ different deleterious mutations were found in 68 families (Table 1). The four most common mutations (c.181T > G, c.1687C > T, c.5266dupC and c.844_850dupTCATTAC) were detected in 44 families (65\%). The additional 14 mutations in BRCA1 appeared in other 24 families

Four of the mentioned 18 mutations are missense mutations affecting the 5'RING domain (c.116G > A, c. $181 \mathrm{~T}>\mathrm{G}$, c.181T > A, c.191G > A), three are nonsense mutations (c.1687C > T, c.5251C > T and c.5377A > T), seven are frame-shift mutations (c.457_458delAG, c.844_850dupTCATTAC, c.843_846delCTCA, c.2269delG, c.3018_3021delTTCA, c.5177_5180delGAAA and c.5266dupC) and four are deletions of the whole exons (Ex1-2 del, Ex5-7 del, Ex5-8 del and Ex5-10 del).

The most common mutation found in BRCA1 gene was c. $181 \mathrm{~T}>\mathrm{G}$. It was detected in 15 families. The patients with ovarian cancer represented $36 \%$ of all breast and ovarian cancer cases in the families bearing the mutation c.181T > G. The average age of the patients at the onset of ovarian cancer was 52.1 years and the average age of the patients at the onset of breast cancer was 48.1 years in these families, respectively. Breast cancer was, in these families, in $56 \%$ of cases detected before the age of 50 . In five families, colorectal cancer, and in two families, cancers of the uterus, were also reported in the family history $(46 \%$ of c. $181 \mathrm{~T}>\mathrm{G}$ families have the HNPCC (hereditary non-polyposis colon cancer) related cancers in their family history).

The second most common mutation in BRCA1 gene in Slovenian families with breast and/or ovarian cancer was c. $1687 \mathrm{C}>\mathrm{T}$. This mutation was observed in 13 families. The patients with ovarian cancer represented $32 \%$ of all breast and ovarian cancer cases in the families bearing the mutation c. $1687 \mathrm{C}>\mathrm{T}$. In these families the average age of the patients at the onset of ovarian cancer was 52.5 years and the average age of the patients at the onset of breast cancer was 46.0. In these families, in $53 \%$ of cases, breast cancer was detected before the age of 50 .

The mutation c.5266dupC in BRCA1 gene was detected in 8 families. The patients with ovarian cancer represented just $9 \%$ of all breast and ovarian cancer cases in the families bearing the c.5266dupC mutation since it was diagnosed in merely 2 cases (onset at 50 and 48 years, respectively). The average age of the patients at the onset of breast cancer in these families was 37.3 years. In more than $89 \%$ of cases, breast cancer was diagnosed before the age of 50 . 
Table 1 Mutations in BRCA1 gene in Slovenian population

\begin{tabular}{|c|c|c|c|c|c|}
\hline $\begin{array}{l}\text { BIC } \\
\text { nomenclature* }\end{array}$ & $\begin{array}{l}\text { HGVS } \\
\text { nomenclature** }\end{array}$ & $\begin{array}{l}\text { Protein change } \\
\text { according to BIC } \\
\text { database }\end{array}$ & $\begin{array}{l}\text { Described in BIC } \\
\text { database (No. of } \\
\text { quotations in BIC) }\end{array}$ & $\begin{array}{l}\text { Present in other than Slovenian } \\
\text { population (No. of families) }\end{array}$ & $\begin{array}{l}\text { No. of positive } \\
\text { Slovenian } \\
\text { families }\end{array}$ \\
\hline $235 G>A$ & C.116G > A & C39Y & yes (4) & & 3 \\
\hline $300 T>G$ & C.181T > G & C61G & yes (202) & $\begin{array}{l}\text { Germany (30), Italy (?), Czech rep (20), } \\
\text { Austria (3), Slovakia (2) }\end{array}$ & 15 \\
\hline $300 \mathrm{~T}>\mathrm{A}$ & C. $181 \mathrm{~T}>\mathrm{A}$ & C61S & no & & 4 \\
\hline $310 \mathrm{G}>\mathrm{A}$ & c.191G > A & C64Y & yes $(20)$ & $\begin{array}{l}\text { Germany (1), Czech rep (1), Canada } \\
\text { (2) }\end{array}$ & 1 \\
\hline 576delAG & c.457_458delAG & $157 X$ & no & & 1 \\
\hline $\begin{array}{l}\text { 963-969 dup } \\
\text { (969ins7) }\end{array}$ & c.844_850dupTCATTAC & $288 X$ & yes (2) & Germany (2) & 8 \\
\hline 962 del4 & c.843_846delCTCA & $297 X$ & yes (17) & $\begin{array}{l}\text { Germany (2), Italy (?), Czech rep (1), } \\
\text { Austria (2), Slovakia (2), Canada } \\
\text { (2- Slavic origin) }\end{array}$ & 2 \\
\hline $1806 \mathrm{C}>\mathrm{T}$ & C. $1687 C>T$ & Q563X & yes (88) & Germany (5), Czech rep (6), Austria (2) & 13 \\
\hline 2388delG & c.2269delG & $764 X$ & yes (7) & & 1 \\
\hline 3137delTTCA & c.3018_3021delTTCA & $1022 X$ & yes (2) & & 1 \\
\hline $\begin{array}{l}5296 \text { del } 4 \\
\text { (GAAA) }\end{array}$ & c.5177_5180delGAAA & $1728 x$ & yes (45) & & 1 \\
\hline $5370 \mathrm{C}>\mathrm{T}$ & $c .5251 C>T$ & R1751X & yes $(30)$ & Germany (1), & 1 \\
\hline 5382insC & c.5266dupC & $1829 x$ & yes (200) & $\begin{array}{l}\text { Germany (46), Italy (?), Czech rep. (75), } \\
\text { Netherlands (5), Austria (2), Slovakia (2) }\end{array}$ & 8 \\
\hline $5496 \mathrm{~A}>\mathrm{T}$ & C.5377A > T & K1793X & no & & 2 \\
\hline Ex1-2del & Ex1-2del & & no & Germany (?),Czech (1) Canada, Spain & 1 \\
\hline Ex5-10 del & Ex5-10 del & & no & & 3 \\
\hline Ex5-8 del & Ex5-8 del & & no & & 1 \\
\hline Ex5-7 del & Ex5-7 del & & no & Spain, Germany & 2 \\
\hline Total BRCA1 & & & & & 68 \\
\hline
\end{tabular}

The mutation c.844_850dupTCATTAC in BRCA1 gene was noticed in 8 families. The patients with ovarian cancer represented $30 \%$ of all breast and ovarian cancers cases in the families bearing the mutation c.844_850dupTCATTAC. The average age of the patients at the onset of ovarian cancer was 53.7 years, while the average age of the patients at the onset of breast cancer was 47.5 years. In $69 \%$ of cases, breast cancer was diagnosed before the age of 50 .

\section{BRCA2 mutation spectrum}

The analysis of the BRCA2 gene revealed 13 different mutations in 28 families (Table 2). The most common mutation in BRCA2 gene is a splice site mutation c.7806-2A > G. It was detected in 11 families (which represents $39 \%$ of all $B R C A 2$ positive families). The remaining 12 BRCA2 mutations were much less frequent in the Slovenian population (each being discovered in 1 to 4 families) (Table 2). They are nonsense mutations or frame-shift mutations causing a truncation of the encoded protein. No large deletions were found in the $B R C A 2$ gene.

The c.7806-2A > G mutation was observed in 11 families. The patients with ovarian cancer (three patients aged 50, 59 and 70 years at the onset of disease) represented only $6 \%$ of all breast and ovarian cancer cases in the families bearing the mutation c.7806-2A > G. The average age of the patients at the onset of breast cancer was 50.9 years. Breast cancer was in $40 \%$ of cases discovered before the age of 50 .

The second most frequent mutation in $B R C A 2$ gene was c.5291C > G. It was detected in four families. The average age of the patients at the onset of breast cancer in these families was 45.5 years. In $72 \%$ of cases, breast cancer was discovered before the age of 50 years. No ovarian cancers were observed in these families.

The third most common mutation in BRCA2 gene occurring in three families was c.3975_3978dupTGCT. 
Table 2 Mutations in BRCA2 gene in Slovenian population

\begin{tabular}{|c|c|c|c|c|c|}
\hline $\begin{array}{l}\text { BIC } \\
\text { nomenclature* }\end{array}$ & $\begin{array}{l}\text { HGVS } \\
\text { nomenclature }\end{array}$ & $\begin{array}{l}\text { Protein change } \\
\text { according to BIC } \\
\text { database }\end{array}$ & $\begin{array}{l}\text { Described in } \mathrm{BIC} \\
\text { database (No. of } \\
\text { quotations in } \mathrm{BIC})\end{array}$ & $\begin{array}{l}\text { Present in other than } \\
\text { Slovenian population (No. of } \\
\text { families) }{ }^{* *}\end{array}$ & $\begin{array}{l}\text { No. of positive } \\
\text { Slovenian } \\
\text { families }\end{array}$ \\
\hline $1003 \mathrm{~A}>\mathrm{T}^{* * * *}$ & c. $775 \mathrm{~A}>\mathrm{T}$ & R259X & no & & 1 \\
\hline $1756 \mathrm{G}>\mathrm{T}$ & c.1528G > T & E510X & yes (1) & & 1 \\
\hline 2041 ins A & c.1813dupA & $615 X$ & yes (97) & Germany (5), Czech rep (2) & 1 \\
\hline $3493 C>T$ & c.3265C > T & Q1089X & yes (1) & & 1 \\
\hline $\begin{array}{l}4206 \text { ins4 } \\
\text { (TGCT) } \\
4203 \text { 4206dupl }\end{array}$ & $\begin{array}{l}\text { c.3978insTGCT } \\
\text { c.3975_3978dupTGCT }\end{array}$ & $1330 x$ & yes & & 3 \\
\hline 5164delGAAA & c.4936_4939delGAAA & $1668 x$ & yes & & 1 \\
\hline $5519 C>G$ & c. $5291 C>G$ & S1764X & no & & 4 \\
\hline 5579insA & c.5351insA c.5351dupA & $1786 X$ & yes & Netherland (6) & 1 \\
\hline $5837 \mathrm{TC}>\mathrm{AG}$ & c.5609_5610delTCinsAG & F1870X & yes (2) & & 1 \\
\hline 6719delAGTT & c.6491_6494delAGTT & $2166 x$ & no & & 1 \\
\hline $7531 C>T$ & c.7303C > T & Q2435X & no & & 1 \\
\hline $\begin{array}{l}\text { IVS16-2A > G } \\
8064-2 A>G\end{array}$ & c.7806-2A > G & aberrant splicing & yes (5) & Germany (2), Italy (2) & 11 \\
\hline $9514 \mathrm{C}>\mathrm{T}$ & c.9286C > T & E3096X & yes (1) & no & 1 \\
\hline$\overline{\text { Total }}$ & & & & & 28 \\
\hline
\end{tabular}

Description of nucleotide variations is in accordance with BIC nomenclature* (DNA variants are numerated according to NCBI reference sequence U43746 for mRNA of BRCA2; the first nucleotide of mRNA is numerated as 1) or HGVS nomenclature** (DNA variants are numerated according to NCBI reference NM_000059.3 for BRCA2; the first nucleotide of the start codon ATG is numerated as 1). ***References: Germany [15]. Italy [15]. Czech Rep [16,45]. Netherland [17]. ****Albanian origin - Kosovo.

The mutation c.3975_3978dupTGCT is located in the "ovarian cluster region" of BRCA2 gene [34,35]. The patients with ovarian cancer (two patients aged 40 and 52 years at the onset of the disease) represented $29 \%$ of all breast and ovarian cancer cases in these families. The average age of the patients at the onset of breast cancer was 52.2 years. In $66 \%$ of cases, breast cancer was detected before the age of 50 years.

\section{Polymorphisms and unclassified sequence variants in BRCA1 and BRCA2 genes}

All sequence variants which were not classified as mutations were categorized either as polymorphisms or as unclassified variants (UVs) according to the BIC database (Breast cancer information core) (Tables 3, 4 and 5). When the sequence variant was not reported in the BIC database, we classified it as a UV. Polymorphisms detected in individuals with breast and ovarian cancer family history and those found in the control group are listed in Table 3, while unclassified variants are given in Tables 4 and 5 .

Unclassified variants were more common in BRCA2 (20 different UVs) than in BRCA1 (12 different UV) (Tables 4 and 5). Most UVs are missense mutations, yet two UVs in the $B R C A 2$ gene cause frame-shift of the open reading frame.

\section{Controls}

The DNA of 40 healthy Slovenian women aged between 50 and 69 years without any personal and familial breast and/or ovarian cancer history was also tested for the presence of all known mutations, UVs and polymorphisms in $B R C A 1$ and $B R C A 2$ genes in Slovenian population. The results are given in the Tables 2 and 3 . No mutations were detected in the control group. All frequent polymorphisms observed in individuals with breast and ovarian cancer family history, with the allele frequency of more than $2 \%$, were detected also in the control group with similar allele frequencies (Table 3).

\section{Mutation detection rates}

The mutation detection rates in different groups and subgroups defined according to the familial cancer history are presented in Tables 6 and 7 .

To estimate the influence of number of breast cancer cases in the family on the mutation detection rate among the families with only breast cancer history, we subdivided Groups $A, C$ and $D$ according to the number of breast cancer cases in the family. The proportions of families with 2, 3 or 4 breast cancers were relatively similar in all three groups (Table 8 ).

The frequency at which $B R C A 1$ and $B R C A 2$ gene mutations were detected in the families belonging to Group $B$ was statistically significantly higher when compared to Groups A, C, D, E and MBR (p-values: 0.034, 0.021, 0.008, $0.006,0.003$, respectively). Also the frequency of mutations seen in Group $A$ was statistically significantly different 
Table 3 Polymorphisms in BRCA1 and BRCA2 genes in Slovenian population

\begin{tabular}{|c|c|c|c|c|c|c|c|}
\hline $\begin{array}{l}\text { BIC } \\
\text { nomenclature* }\end{array}$ & $\begin{array}{l}\text { HGVS } \\
\text { nomenclature** }\end{array}$ & $\begin{array}{l}\text { Protein } \\
\text { change }\end{array}$ & Allele & $\begin{array}{l}\text { No. of alleles/all } \\
\text { alleles of tested } \\
\text { probands (allele } \\
\text { frequencies) }\end{array}$ & $\begin{array}{l}\text { No. of alleles/all alleles of } \\
\text { tested healthy individuals } \\
\text { (allele frequencies) }\end{array}$ & $\begin{array}{l}\text { Described } \\
\text { in BIC } \\
\text { database }\end{array}$ & $\begin{array}{l}\text { Clinical importance } \\
\text { entered in BIC } \\
\text { database (allele } \\
\text { frequencies) }\end{array}$ \\
\hline \multicolumn{8}{|l|}{ BRCA1 } \\
\hline $710 \mathrm{C}>\mathrm{T}$ & c.591C > T & C197C & $\mathrm{T}$ & $1 / 380(0.003)$ & 0/80 (0.000) & yes & no $(0.02)$ \\
\hline $1186 \mathrm{~A}>\mathrm{G}$ & c. $1067 A>G$ & Q356R & G & $25 / 380(0.065)$ & $6 / 80(0.075)$ & yes & no (0.06) \\
\hline $2196 G>A$ & c. $2077 \mathrm{G}>\mathrm{A}$ & D693N & A & 6/208 (0.029) & $4 / 80(0.050)$ & yes & no (0.08) \\
\hline $2201 C>T$ & c. $2082 C>T$ & S694S & $\mathrm{T}$ & $66 / 208(0.32)$ & $25 / 80(0.31)$ & yes & no $(0.31)$ \\
\hline $2430 T>C$ & c. $2311 \mathrm{~T}>\mathrm{C}$ & L771L & C & $66 / 208(0.32)$ & $25 / 80(0.31)$ & yes & no $(0.31)$ \\
\hline $2731 C>T$ & c. $2612 C>T$ & P871L & $\mathrm{T}$ & $66 / 208(0.32)$ & $25 / 80(0.31)$ & yes & no (0.34) \\
\hline $3232 A>G$ & c. $3113 \mathrm{~A}>\mathrm{G}$ & E1038G & G & $66 / 208(0.32)$ & $25 / 80(0.31)$ & yes & no $(0.31)$ \\
\hline $3667 A>G$ & c. $3548 \mathrm{~A}>\mathrm{G}$ & K1183G & $\mathrm{G}$ & $66 / 208(0.32)$ & 25/80 (0.31) & yes & no $(0.31)$ \\
\hline $4427 \mathrm{~T}>\mathrm{C}$ & c.4308T > C & F1436S & $C$ & $66 / 208(0.32)$ & $25 / 80(0.31)$ & yes & no $(0.31)$ \\
\hline $4956 A>G$ & c. $4837 A>G$ & S1613G & $G$ & $66 / 208(0.32)$ & $25 / 80(0.31)$ & yes & no $(0.31)$ \\
\hline \multicolumn{8}{|l|}{ BRCA2 } \\
\hline $203 G>A$ & c. $1-25 G>A$ & 5'-UTR & A & $66 / 208(0.32)$ & $25 / 80(0.31)$ & yes & no $(0.25)$ \\
\hline $1093 A>C$ & C. $865 \mathrm{~A}>\mathrm{C}$ & $\mathrm{N} 289 \mathrm{H}$ & C & 18/380 (0.047) & $3 / 80(0.038)$ & yes & no (?) \\
\hline $1342 C>A$ & c. $1114 C>A$ & $\mathrm{H} 372 \mathrm{~N}$ & $A$ & $160 / 208(0.77)$ & $56 / 80(0.70)$ & yes & no (0.72) \\
\hline $1379 \mathrm{C}>\mathrm{T}$ & C. $1151 C>T$ & S384F & $\mathrm{T}$ & $1 / 208(0.005)$ & 0/80 (0.000) & yes & no (?) \\
\hline $1593 A>G$ & c. $1365 A>G$ & S455S & G & $7 / 208(0.034)$ & $3 / 80(0.038)$ & yes & no $(0.01)$ \\
\hline $2020 A>G$ & C. $1792 A>G$ & T598A & G & 4/208 (0.019) & 0/80 (0.000) & yes & no (?) \\
\hline $2457 \mathrm{~T}>\mathrm{C}$ & c.2229T > C & $\mathrm{H} 743 \mathrm{H}$ & C & $18 / 380(0.047)$ & $5 / 80(0.063)$ & yes & no (?) \\
\hline $3199 A>G$ & c. $2971 A>G$ & N991D & G & $7 / 208$ (0.034) & 3/80 (0.038) & yes & no (?) \\
\hline $3624 A>G$ & c.3396A > G & L1132L & G & 73/208 (0.35) & $38 / 80(0.48)$ & yes & no $(0.31)$ \\
\hline $4035 T>C$ & c.3807T > C & V1269V & $C$ & $27 / 208(0.130)$ & $18 / 80(0.225)$ & yes & no (0.19) \\
\hline $4486 \mathrm{G}>\mathrm{T}$ & c.4258G > T & D1420Y & $\mathrm{T}$ & $3 / 208(0.014)$ & 0/80 (0.000) & yes & no (?) \\
\hline $5427 \mathrm{C}>\mathrm{T}$ & c. $5199 C>T$ & S1733S & $\mathrm{T}$ & 4/208 (0.019) & 4/80 (0.050) & yes & no (?) \\
\hline $7470 A>G$ & c.7242A > G & S2414S & G & $57 / 208(0.27)$ & $21 / 80(0.26)$ & yes & no $(0.21)$ \\
\hline $8034-14 C>T$ & c.7806-14C > T & intron & $\mathrm{T}$ & 95/208 (0.46) & $33 / 80(0.41)$ & yes & no $(0.50)$ \\
\hline $8410 G>A$ & $\mathrm{C} .8182 \mathrm{G}>\mathrm{A}$ & V2728I & A & $1 / 208(0.005)$ & $1 / 80(0.013)$ & yes & no (?) \\
\hline 10323delCins11 & 10095delCins 11 & $3369 x$ & del & $3 / 380(0.008)$ & 0/80 (0.000) & yes & no (?) \\
\hline
\end{tabular}

Description of nucleotide variations is in accordance with BIC nomenclature* (DNA variants are numerated according to NCBI reference sequence HSU14680 for mRNA of $B R C A 1$, or U43746 for mRNA of BRCA2; the first nucleotide of mRNA is numerated as 1) or HGVS nomenclature** (DNA variants are numerated according to NCBI reference sequence NM_007294.2 for BRCA1, NM_000059.3 for BRCA2; the first nucleotide of the start codon ATG is numerated as 1). UTR - untranslated region. (?)-data unknown.

from those observed in Groups $C, D, E$ and $M B R$, respectively (p-values $<0.001$ in all four cases) (Table 6).

\section{Discussion}

Genetic counseling and testing of individuals from families with an increased risk of breast and/or ovarian cancer in Slovenia has been available at the Institute of Oncology Ljubljana since 1999. From then and until January 2009, we screened 322 families and we detected a highly penetrant $B R C A 1$ and BRCA2 mutation in 96 of them. In this study, we are summarizing the most significant features of hereditary breast and ovarian cancer in Slovenian families. The overall mutation detection rate in our series was $21.1 \%$ for $B R C A 1$ and $8.7 \%$ for $B R C A 2$; for both genes, it was $29.8 \%$.

In general, the mutation detection rates for $B R C A 1$ and $B R C A 2$ genes in the members of Slovenian families with breast and/or ovarian cancer are comparable with the mutation frequencies in these two genes reported for other countries $[15,17,25]$. When comparing the study groups, the highest mutation detection rate in Slovenian population was observed in the families with at least one breast and at least one ovarian cancer (Group $B$ ) - $42 \%$ for BRCA1 and $8 \%$ for BRCA2 or $50 \%$ for both genes (Table 6). Similar mutation detection rates for families with the same characteristics were reported in 
Table 4 Unclassified sequence variants in BRCA1 gene in Slovenian population

\begin{tabular}{|c|c|c|c|c|c|c|c|}
\hline $\begin{array}{l}\text { BIC } \\
\text { nomenclature* }\end{array}$ & $\begin{array}{l}\text { HGVS } \\
\text { nomenclature }\end{array}$ & $\begin{array}{l}\text { Protein } \\
\text { change }\end{array}$ & Allele & $\begin{array}{l}\text { No. of alleles/all alleles } \\
\text { of tested probands } \\
\text { (allele frequencies) }\end{array}$ & $\begin{array}{l}\text { No. of alleles/all alleles of } \\
\text { tested healthy individuals } \\
\text { (allele frequencies) }\end{array}$ & $\begin{array}{l}\text { Described } \\
\text { in BIC } \\
\text { database }\end{array}$ & $\begin{array}{l}\text { Clinical } \\
\text { importance } \\
\text { entered in BIC } \\
\text { database }\end{array}$ \\
\hline \multicolumn{8}{|c|}{ Missense changes } \\
\hline $212 C>G$ & $c .93 C>G$ & I31M & $G$ & $3 / 380(0.008)$ & $0 / 80(0.000)$ & yes & unknown \\
\hline $462 C>A$ & c. $343 C>A$ & P115S & A & $1 / 208(0.005)$ & 0/80 (0.000) & no & \\
\hline $1112 G>C$ & c.993G > C & R331S & C & $2 / 208(0.010)$ & $0 / 80(0.000)$ & yes & unknown \\
\hline $3238 G>A$ & c. $3119 \mathrm{G}>\mathrm{A}$ & S1040N & A & 5/208 (0.024) & 0/80 (0.000) & yes & unknown \\
\hline $3421 \mathrm{G}>\mathrm{A}$ & c. $3302 \mathrm{G}>\mathrm{A}$ & S1101N & A & $1 / 208(0.005)$ & 0/80 (0.000) & yes & unknown \\
\hline $3573 G>A$ & c.3454G > A & D1152N & A & 1/208 (0.005) & 0/80 (0.000) & yes & unknown \\
\hline $3768 \mathrm{~T}>\mathrm{C}$ & c.3649T > C & S1217P & C & $1 / 208(0.005)$ & 0/80 (0.000) & no & \\
\hline $4158 \mathrm{~A}>\mathrm{G}$ & c. $4039 A>G$ & R1347G & G & 2/208 (0.010) & 0/80 (0.000) & yes & unknown \\
\hline $4384 G>A$ & C. $4265 G>A$ & G1422E & A & $1 / 208(0.005)$ & 0/80 (0.000) & no & \\
\hline $4675 A>G$ & c. $4556 \mathrm{~A}>\mathrm{G}$ & N1519S & $G$ & $1 / 208(0.005)$ & $0 / 80(0.000)$ & no & \\
\hline $5075 G>A$ & c. $4956 \mathrm{G}>\mathrm{A}$ & M1652I & A & $3 / 208(0.014)$ & 0/80 (0.000) & yes & unknown \\
\hline $5124 G>T$ & c. $5005 \mathrm{G}>\mathrm{T}$ & A1669S & $\mathrm{T}$ & $1 / 208(0.005)$ & 0/80 (0.000) & yes & unknown \\
\hline
\end{tabular}

Description of nucleotide variations is in accordance with BIC nomenclature* (DNA variants are numerated according to NCBI reference sequence HSU14680 for mRNA of BRCA1; the first nucleotide of mRNA is numerated as 1) or HGVS nomenclature** (DNA variants are numerated according to NCBI reference sequence NM_007294.2 for BRCA1; the first nucleotide of the start codon ATG is numerated as 1). UV- unclassified variant.

other populations - $53 \%$ in the German population, $43.7 \%$ in the Italian population, $43 \%$ in the Spanish population, and $52 \%$ in the Dutch population $[15,17,23,25]$.

However, with the additional subdividing of groups in our study, even higher mutation detection rate (of 85\%) was observed in the subgroup of families with two or more ovarian cancers and only one breast cancer (Subgroup - more $O+1 B)$. On the other hand, the proportion of detected mutations in BRCA1 and BRCA2 genes fell to $36 \%$ when we investigated the subgroup of families with at least two ovarian cancers and no breast cancer in their family history (Subgroup - only O) (Table 7). Similar findings were perceived by Ramus et al. In their studies, the frequency of BRCA1 and BRCA2 mutations in the families with site-specific ovarian cancer was lower than in the families with breast and ovarian cancer. The families with three or more ovarian cancers and at least one breast cancer had mutations in BRCA1 and $B R C A 2$ in $81 \%$ of cases (similar to our results) while in the families with three or more ovarian cancers and no breast cancer mutations in BRCA1 or BRCA2 were detected in only $63 \%$ (which is still much higher than in our study) $[34,35]$. In the Dutch population, the mutation detection rate in the families with at least two ovarian cancers and one or more breast cancers was $82 \%$, whereas in the families with only ovarian cancer history, it was $36 \%$, which is quite similar to our detection rates [17].

This lower mutation detection rate in the families with ovarian cancers only indicates the existence of other (different from $B R C A 1 / 2$ ) predisposing genes in hereditary ovarian cancers [36]. It is well known that hereditary ovarian cancer can be associated also with Lynch syndrome and with mutations in mismatch repair genes [35].

If we gather all families with at least two breast cancers in their family history regardless of the age at the disease onset and no ovarian cancer, the mutation detection rate in the Slovenian population is $24 \%$. For comparison, the mutation detection rate for BRCA1 and $B R C A 2$ in similar groups of families in the Dutch, German, Italian and Spanish population is $13 \%, 24 \%$, $18.5 \%$ and $15 \%$, respectively $[15,17,23,25]$. In the families with two or more breast cancer cases and at least two of them diagnosed under the age of 50 and no ovarian cancer (Group $A$ ), the mutation detection rate for $B R C A 1$ is $23 \%$ and for $B R C A 2$ is $13 \%$ or $36 \%$ for both genes in the Slovenian population, $27 \%$ in the Dutch population and $37 \%$ in the German population $[15,17]$.

In the group of families with no ovarian cancer but at least two or more breast cancer cases with only one of them diagnosed before the age of 50 (Group $C$ ), the mutation detection rate for $B R C A 1$ was $11 \%$ and for BRCA2 $8 \%$ or $19 \%$ for both genes. These detection rates are slightly higher than the detection rates reported by the German study group ( $7 \%$ and $3 \%$ for $B R C A 1$ and $B R C A 2$, respectively) [15]. In the Dutch population, the mutation detection rate for both BRCA1 and BRCA2 in this group of families was $15 \%$ [17].

When considering our families with at least two breast cancers and all of them diagnosed after age of 50 and no ovarian cancer (Group D), the mutation detection rate 
Table 5 Unclassified sequence variants in BRCA2 gene in Slovenian population

\begin{tabular}{|c|c|c|c|c|c|c|c|}
\hline $\begin{array}{l}\text { BIC } \\
\text { nomenclature* }\end{array}$ & $\begin{array}{l}\text { HGVS } \\
\text { nomenclature** }\end{array}$ & $\begin{array}{l}\text { Protein } \\
\text { change }\end{array}$ & Allele & $\begin{array}{l}\text { No. of alleles/all alleles } \\
\text { of tested probands } \\
\text { (allele frequencies) }\end{array}$ & $\begin{array}{l}\text { No. of alleles/all alleles of } \\
\text { tested healthy individuals } \\
\text { (allele frequencies) }\end{array}$ & $\begin{array}{l}\text { Described } \\
\text { in BIC } \\
\text { database }\end{array}$ & $\begin{array}{l}\text { Clinical } \\
\text { importance } \\
\text { entered in BIC } \\
\text { database }\end{array}$ \\
\hline \multicolumn{8}{|c|}{ Missense changes } \\
\hline $2032 G>A$ & c.1804G > A & G602R & A & $1 / 208(0.005)$ & 0/80 (0.000) & yes & unknown \\
\hline $3747 C>T$ & c. $3519 C>T$ & S1152L & $T$ & $1 / 208(0.005)$ & $0 / 80(0.000)$ & no & \\
\hline $5078 \mathrm{G}>\mathrm{A}$ & c. $4850 \mathrm{G}>\mathrm{A}$ & S1617N & $\mathrm{A}$ & $1 / 208(0.005)$ & $0 / 80(0.000)$ & no & \\
\hline $5972 C>T$ & c. $5744 \mathrm{C}>\mathrm{T}$ & T1915M & $T$ & $14 / 208(0,067)$ & $3 / 80(0.038)$ & yes & unknown \\
\hline $8107 \mathrm{~A}>\mathrm{T}$ & c.7879A > T & $12627 \mathrm{~F}$ & $\mathrm{~T}$ & $1 / 380(0.003)$ & 0/80 (0.000) & yes & unknown \\
\hline $8482 \mathrm{~A}>\mathrm{T}$ & c. $8254 \mathrm{~A}>\mathrm{T}$ & $12752 \mathrm{~F}$ & $T$ & $1 / 208(0.005)$ & 0/80 (0.000) & yes & unknown \\
\hline $8579 G>A$ & c. $8351 G>A$ & R2784Q & $A$ & $2 / 380(0.005)$ & 0/80 (0.000) & yes & unknown \\
\hline $9133 \mathrm{G}>\mathrm{A}$ & c.8905G > A & V2969M & A & $2 / 380(0.005)$ & 0/80 (0.000) & yes & unknown \\
\hline $9599 \mathrm{~A}>\mathrm{T}$ & C. $9371 \mathrm{~A}>\mathrm{T}$ & N3124I & AT & $1 / 380(0.003)$ & 0/80 (0.000) & yes & unknown \\
\hline $10462 A>G$ & $10234 A>G$ & $13412 \mathrm{~V}$ & G & $1 / 208(0.005)$ & $0 / 80(0.000)$ & yes & unknown \\
\hline
\end{tabular}

Frameshift changes

\begin{tabular}{lllllll}
\hline 4091delTAA & c.3863delTAA & del288N & del & $2 / 208(0.010)$ & $0 / 80(0.000)$ & no \\
\hline 9512dupl12 & c.9284_9295dup12 & & dup & $1 / 380(0.003)$ & $0 / 80(0.000)$ & \\
\hline Intron changes & & & & & & \\
\hline IVS2-7A $>$ T & c.68-7A $>$ T & intron & $T$ & $1 / 208(0.005)$ & $1 / 80(0.013)$ & yes
\end{tabular}

\begin{tabular}{|c|c|c|c|c|c|c|c|}
\hline \multicolumn{8}{|c|}{ Synonymous changes } \\
\hline $1395 G>A$ & c. $1167 G>A$ & P389P & A & $1 / 208(0.005)$ & $0 / 80(0.000)$ & no & \\
\hline $1977 G>A$ & C.1749G > A & L583L & $A$ & $1 / 208(0.005)$ & 0/80 (0.000) & no & \\
\hline $4296 G>A$ & c. $4068 G>A$ & L1356L & A & $3 / 208(0.014)$ & 0/80 (0.000) & yes & unknown \\
\hline $5013 G>A$ & C. $4785 G>A$ & Q1595Q & A & $1 / 208(0.005)$ & $0 / 80(0.000)$ & no & \\
\hline $5985 G>A$ & c. $5757 G>A$ & L1919L & G & 0/208 (0.000) & 1/80 (0.013) & no & \\
\hline $10431 G>A$ & $10203 G>A$ & T3401T & $A$ & $1 / 208(0.005)$ & 0/80 (0.000) & no & \\
\hline
\end{tabular}

Description of nucleotide variations is in accordance with BIC nomenclature* (DNA variants are numerated according to NCBI reference sequence U43746 for mRNA of BRCA2.; the first nucleotide of mRNA is numerated as 1) or HGVS nomenclature** (DNA variants are numerated according to NCBI reference sequence NM_000059.3 for BRCA2; the first nucleotide of the start codon ATG is numerated as 1).

was $5 \%$ (only one mutation discovered in BRCA2). In the Dutch population, the reported mutation detection rate in similar group of families was $6 \%$ and for the German population $10 \%[15,17]$. Since the mutation detection rate in the families with the same number of breast cancer cases is higher in the group with earlier disease onset (Group $A$ ) than in the groups with later disease onset (Groups $C$ and $D$ ), the age at the disease onset seems to influence the BRCA1/2 mutation detection rate (Table 8). A rather low mutation detection rate in the group with breast cancers diagnosed at the age over 50 years suggests that other potential predisposing genes confer an increased risk of postmenopausal breast cancer [37].

The families with a single male breast cancer case and no other breast/ovarian cancers among first degree relatives (Group $M B R$ ) had the mutation detection rate of

Table 6 Incidence of BRCA1 or BRCA2 mutations among different groups of Slovenian families defined according to family history

\begin{tabular}{|c|c|c|c|c|c|c|}
\hline Group & $A$ & $B$ & $C$ & $D$ & $E$ & $M B R$ \\
\hline \multicolumn{7}{|c|}{ No. of mutation positive families (\%)* } \\
\hline BRCA1 positive & 18/77 (23\%) & $42 / 100(42 \%)$ & 8/75 (11\%) & $0 / 21(0 \%)$ & $2 / 24(8 \%)$ & $0 / 25(0 \%)$ \\
\hline BRCA2 positive & $10 / 77(13 \%)$ & $8 / 100(8 \%)$ & $6 / 75(8 \%)$ & $1 / 21(5 \%)$ & $0 / 24(0 \%)$ & $1 / 25(4 \%)$ \\
\hline
\end{tabular}

*number of positive families/number of all tested families in the group (the proportion of positive families). Group $A$ - families with two or more cases of breast cancer including at least two cases with the disease onset under the age of 50 and with no ovarian cancer. Group $B$ - families with one or more cases of breast and at least one ovarian cancer. Group C - families with two or more cases of breast cancer including one case diagnosed before the age of 50 and with no ovarian cancer. Group D - families with two or more cases of breast cancer all of them diagnosed beyond the age of 50 and with no ovarian cancer. Group $E$ families with a single case of breast cancer diagnosed at the age under 40 years. Group MBR - families with a single male breast cancer. Bilateral breast cancers were considered as two separate cases of cancer. 
Table 7 Incidence of BRCA1 or BRCA2 mutations among different sub-groups of Slovenian families with breast and ovarian cancer

\begin{tabular}{|c|c|c|c|c|c|c|}
\hline Sub-group & $B A$ & $B C$ & $B D$ & $1 B+10$ & MoreO+1B & Only 0 \\
\hline \multicolumn{7}{|c|}{ No. of mutation positive families (\%)* } \\
\hline BRCA1 positive & 10/19 (53\%) & 14/21 (67\%) & $2 / 7(29 \%)$ & $8 / 32(25 \%)$ & $6 / 7(86 \%)$ & $4 / 14(29 \%)$ \\
\hline BRCA2 positive & $1 / 19(5 \%)$ & $2 / 21(10 \%)$ & $2 / 7(29 \%)$ & $3 / 32(9 \%)$ & $0 / 7(0 \%)$ & $1 / 14(7 \%)$ \\
\hline
\end{tabular}

*number of positive families/number of all tested families in the group (the proportion of positive families). Group $B$ (families with one or more cases of breast and at least one ovarian cancer) was further subdivided into sub-groups: $B A$ - families with at least one ovarian cancer and at least two breast cancers diagnosed under the age of 50; $B C$ - families with at least one ovarian cancer and at least two breast cancers, one of them diagnosed under the age of 50 ; $B D$ - families with at least one ovarian cancer and at least two breast cancers all of them diagnosed beyond the age of $50 ; 1 B+10$ - families with only one ovarian cancer and one breast cancer in the family or only one affected individual in the family, but having both types of cancer at the same time; more $O+1 B$ - families with at least two ovarian cancers and only one breast cancer; only $O$ - families with at least two ovarian cancers and no breast cancer.

$4 \%$ for $B R C A 2$ and $0 \%$ for $B R C A 1$. Yet, when taken together, all families with male breast cancer in their family history had the mutation detection rate of $11.5 \%$ (3 positive families from 26 tested families) [38]. The mutations detected in male breast cancer were c.7806-2A $>$ G and c.3975_3978dupTGCT in BRCA2 gene. In comparison, the mutation detection rates in the families with male breast cancer in the German population were $25 \%$, (12 positive cases from 47 tested families) and as high as $42 \%$ in Italian ( 3 positive cases from 7 tested families) and in the Dutch population (5 positive cases from 12 tested families), which is much higher than in our population $[15,17,25]$. In this place, it must definitely be stressed that, in our study, not all samples of male breast cancer have been fully screened up till now and that only tests for the most frequent mutations in the Slovenian population have been performed. This might be one of the possible reasons for a lower mutation detection rate in this group of families in our population.

Nevertheless, a low detection rate has also been perceived in another group of families with a single case of female breast cancer (Group E) where the mutation detection rates for $B R C A 1$ and for $B R C A 2$ were $8 \%$ and $0 \%$, respectively. In the German population, the detection rates in this group are reported to be $8 \%$ in $B R C A 1$ and $4 \%$ in BRCA2 [15].

The majority of common mutations in BRCA1 (c.181T > G, c.1687C > T, c.5266dupC) observed in the Slovenian population have been frequently described also in other European populations (Table 1), but not the mutation c.844_850dupTCATTAC. This mutation has been previously described only twice in the German population, while it was found in as many as 8 families in the Slovenian population. Another rare mutation in BRCA1 - the mutation c.181T > A has also been previously described only in the Slovenian population [39].

In $B R C A 2$, the most frequent mutations were c.78062A > G, c.5291C > G and c.3975_3978dupTGCT. The mutation c.7806-2A > G has been already reported by our group [31]. It is a Slovenian founder mutation, reported before also by others $[15,40,41]$. The mutation c.5291C > G, however, according to BIC database, has not been described in any other populations, other then the Slovenian one.

Different mutations in $B R C A 1$ and $B R C A 2$ genes have a different penetrance for breast and for ovarian cancer [35]. This has been observed also in our population. The families affected by one mutation actually differ from the families affected by another mutation by means of the proportion of ovarian cancers among all breast and ovarian cancers in the family. These differences can be due to the variations in the biology of the translated protein having a different effect on the normal breast or ovarian tissue. The difference could also be associated with other than BRCA1 and BRCA2 common moderate/low penetrance genes in the population $[35,42,43]$.

Table 8 Incidence of BRCA1 or BRCA2 mutations among Slovenian families with only breast cancer history (no ovarian cancer) subdivided according to the number of breast cancer cases in the family

\begin{tabular}{lllll}
\hline $\begin{array}{l}\text { Group } \\
\text { history* }\end{array}$ & $\begin{array}{l}\mathbf{2} \text { breast cancers in family } \\
\text { history* }\end{array}$ & $\begin{array}{l}\mathbf{3} \text { breast cancers in family } \\
\text { history* }\end{array}$ & $\begin{array}{l}\mathbf{4} \text { breast cancers in family } \\
\text { histore }\end{array}$ & $\begin{array}{l}\text { more then } \mathbf{5} \text { breast cancers in family } \\
\text { history* }\end{array}$ \\
\hline C & $9 / 29(31 \%)$ & $5 / 21(24 \%)$ & $7 / 16(43 \%)$ & $7 / 11(64 \%)$ \\
\hline$D$ & $5 / 37(13 \%)$ & $3 / 25(12 \%)$ & $4 / 9(44 \%)$ & $2 / 4(50 \%)$ \\
\hline
\end{tabular}

*number of positive families/number of all tested families in the group (the proportion of positive families). Group A - families with two or more cases of breast cancer including at least two of them diagnosed under the age of 50 and with no ovarian cancer. Group $C$ - families with two or more cases of breast cancer including one case diagnosed before the age of 50 and with no ovarian cancer. Group $D$ - families with two or more cases of breast cancer all of them diagnosed beyond the age of 50 years and with no ovarian cancer. 


\section{Conclusion}

With the introduction of the genetic councelling and testing into clinical oncology the approach to individuals and families at elevated risk for specific cancer changed radically. It offers namely not only the identification of individuals at risk but also planning of different prevention strategies that may reflect in longer life expectancies of these individuals. In our study, 96 families bearing the $B R C A 1$ or $B R C A 2$ mutation were identified. The mutation detection rates for BRCA1 and BRCA2 genes in different groups of families with different family history were similar to the mutation detection rates in other European populations. The most common mutations in the BRCA1 gene in the families with an increased risk of breast and/or ovarian cancer in Slovenia are c. $181 \mathrm{~T}>\mathrm{G}, \mathrm{c} .1687 \mathrm{C}>\mathrm{T}$, c.5266dupC, c.844_850dupTCATTAC and c.181T > A. The most frequent mutations in BRCA2 are c.7806-2A > G, c.5291C $>\mathrm{G}$ and c.3975_3978dupTGCT. The cumulative share of these frequent mutations in BRCA1 and BRCA2 genes in Slovenian families affected with mutations is $68.7 \%$. In the Slovenian population, the mutation detection rate seems to be influenced by the presence of ovarian cancer history, the age at the diagnosis of breast cancers in the family and the number of breast cancer cases in the family. As well, the mutation detection rate might further be influenced in the future - it might namely increase when the character of some of the unclassified variants will be clarified as pathogenic.

\section{Acknowledgements \\ The authors gratefully thank the genetic counselors and nurses as well as laboratory technicians who helped to recruit patients, collect their clinical data and perform the analyses, Nikola Bešič, Aleš Vakselj, Cvetka Bilban- Jakopin, Kristijana Hertl, Alenka Vrečar, Katarina Lokar, and Simona Traven. Authors also thank Barbara Jezeršek-Novaković for reviewing the article.}

\section{Author details}

${ }^{1}$ Department of Molecular Diagnostics, Institute of Oncology Ljubljana, Zaloska 2, 1000 Ljubljana, Slovenia. ${ }^{2}$ Unit of Genetic Counseling, Institute of Oncology Ljubljana, Zaloska 2, 1000 Ljubljana, Slovenia. ${ }^{3}$ Department of Surgical Oncology, Institute of Oncology Ljubljana, Zaloska 2, 1000 Ljubljana, Slovenia. ${ }^{4}$ Laboratory of Molecular Oncology, Oncologisch Centrum UZ Brussel, Laarbeeklaan 101, 1090 Brussels, Belgium.

\section{Authors' contributions}

VS, MK, JŽ, MH, ET, JG and SN designed the study, collected and analyzed the data and wrote the paper.

\section{Competing interests}

The authors declare that they have no competing interest.

Received: 15 October 2010 Accepted: 14 January 2011

Published: 14 January 2011

\section{References}

1. Primic Žakelj M, Bračko M, Hočevar M, Krajc M, Pompe Kirn V, Strojan P, Zadnjik V, Zakotnik B, Žagar T, eds: Cancer in Slovenia 2007. Ljubljana, Institute of Oncology Ljubljana, Epidemiology and Cancer Registry, Cancer Registry of Republic of Slovenia; 2010.
2. Claus EB, Risch N, Thompson WD: Genetic analysis of breast cancer in the cancer and steroid hormone study. Am J Hum Genet 1991, 48(2):232-42.

3. Miki Y, Swensen J, Shattuck-Eidens D, Futreal PA, Harshman K, Tavtigian S, Liu Q, Cochran C, Bennett LM, Ding W, Bell R, Rosenthal J, Hussey C, Tran T, McClure M, Frye C, Hattier T, Phelps R, Haugen-Strano A, Katcher $H_{\text {, }}$ Yakumo K, Gholami Z, Shaffer D, Stone S, Bayer S, Wray C, Bogden R, Dayananth P, Ward J, Tonin P, Narod S, Bristow PK, Norris FH, Helvering L, Morrison P, Rosteck P, Lai M, Barrett JC, Lewis C, Neuhasen S, CannonAlbright L, Goldgar D, Wiseman R, Kamb A, Skolnick MH: A strong candidate for the breast and ovarian cancer susceptibility gene BRCA1. Science 1994, 266(5182):66-71.

4. Wooster R, Bignell G, Lancaster J, Swift S, Seal S, Mangion J, Collins N, Gregory S, Gumbs C, Micklem G: Identification of the breast cancer susceptibilitygene BRCA2. Nature 1995, 378(6559):789-92.

5. Smith SA, Easton DF, Evans DG, Ponder BA: Allele losses in the region 17q12-21 in familial breast and ovarian cancer involve the wild-type chromosome. Nat Genet 1992, 2(2):128-31.

6. Collins N, McManus R, Wooster R, Mangion J, Seal S, Lakhani SR, Ormiston W, Daly PA, Ford D, Easton DF, Stratton MR: Consistent loss of the wild type allele in breast cancers from a family linked to the BRCA2 gene on chromosome 13q12-13. Oncogene 1995, 10(8):1673-5.

7. Ford D, Easton DF, Bishop DT, Narod SA, Goldgar DE: Risks of cancer in BRCA1-mutation carriers. Lancet 1994, 343(8899):692-5, Breast Cancer Linkage Consortium.

8. Easton DF, Ford D, Bishop DT: Breast and ovarian cancer incidence in BRCA1-mutation carriers. Am J Hum Genet 1995, 56(1):265-71, Breast Cancer Linkage Consortium.

9. Couch FJ, Farid LM, DeShano ML, Tavtigian SV, Calzone K, Campeau L, Peng Y, Bogden B, Chen Q, Neuhausen S, Shattuck-Eidens D, Godwin AK, Daly M, Radford DM, Sedlacek S, Rommens J, Simard J, Garber J, Merajver S, Weber BL: BRCA2 germline mutations in male breast cancer cases and breast cancer families. Nat Genet 1996, 13(1):123-5.

10. Antoniou A, Pharoah PD, Narod S, Risch HA, Eyfjord JE, Hopper JL, Loman N, Olsson H, Johannsson O, Borg A, Pasini B, Radice P, Manoukian S, Eccles DM, Tang N, Olah E, Anton-Culver H, Warner E, Lubinski J, Gronwald J, Gorski B, Tulinius H, Thorlacius S, Eerola H, Nevanlinna H, Syrjäkoski K, Kallioniemi OP, Thompson D, Evans C, Peto J, Lalloo F, Evans DG, Easton DF: Average risks of breast and ovarian cancer associated with BRCA1 or BRCA2 mutations detected in case Series unselected for family history: a combined analysis of 22 studies. Am J Hum Genet 2003, 72(5):1117-30.

11. King MC, Marks JH, Mandell JB, New York Breast Cancer Study Group: Breast and ovarian cancer risks due to inherited mutations in BRCA1 and BRCA2. Science 2003, 302(5645):643-6.

12. Narod SA, Ford D, Devilee $P$, Barkardottir RB, Lynch HT, Smith SA, Ponder BA, Weber BL, Garber JE, Birch JM, Cornelis RS, Kelsell DP, Spurr NK, Smyth E, Haites N, Sobol H, Bignon YJ, Chang-Claude J, Hamann U, Lindblom A, Borg AM, Steven Piver MS, Gallion HH, Struewing JP, Whittemore A, Tonin P, Goldgar DE, Easton DF: An evaluation of genetic heterogeneity in 145 breast-ovarian cancer families. Am J Hum Genet 1995, 56(1):254-64, Breast Cancer Linkage Consortium.

13. Chen $S$, Iversen ES, Friebel T, Finkelstein D, Weber BL, Eisen A, Peterson LE, Schildkraut JM, Isaacs C, Peshkin BN, Corio C, Leondaridis L, Tomlinson G, Dutson D, Kerber R, Amos Cl, Strong LC, Berry DA, Euhus DM, Parmigiani G: Characterization of BRCA1 and BRCA2 mutations in a large United States sample. J Clin Oncol 2006, 24(6):863-71.

14. Ford D, Easton DF, Stratton M, Narod S, Goldgar D, Devilee P, Bishop DT, Weber B, Lenoir G, Chang-Claude J, Sobol H, Teare MD, Struewing J, Arason A, Scherneck S, Peto J, Rebbeck TR, Tonin P, Neuhausen S, Barkardottir R, Eyfjord J, Lynch H, Ponder BA, Gayther SA, ZeladaHedman M: Genetic heterogeneity and penetrance analysis of the BRCA1 and BRCA2 genes in breast cancer families. Am J Hum Genet 1998, 62(3):676-89, The Breast Cancer Linkage Consortium.

15. Meindl A, German Consortium for Hereditary Breast and Ovarian Cancer: Comprehensive analysis of 989 patients with breast or ovarian cancer provides BRCA1 and BRCA2 mutation profiles and frequencies for the German population. Int J Cancer 2002, 97(4):472-80.

16. Machackova E, Foretova L, Lukesova M, Vasickova P, Navratilova M, Coene I, Pavlu H, Kosinova V, Kuklova J, Claes K: Spectrum and characterisation of BRCA1 and BRCA2 deleterious mutations in high-risk Czech patients with breast and/or ovarian cancer. BMC Cancer 2008, 20(8):140. 
17. Verhoog LC, van den Ouweland AM, Berns E, van Veghel-Plandsoen MM, van Staveren IL, Wagner A, Bartels CC, Tilanus-Linthorst MM, Devilee P, Seynaeve C, Halley DJ, Niermeijer MF, Klijn JG, Meijers-Heijboer H: Large regional differences in the frequency of distinct BRCA1/BRCA2 mutations in 517 Dutch breast and/or ovarian cancer families. Eur J Cancer 2001, 37(16):2082-90.

18. Stoppa-Lyonnet $D$, Laurent-Puig $P$, Essioux L, Pagès $S$, Ithier $G$, Ligot $L$, Fourquet A, Salmon RJ, Clough KB, Pouillart $P$, Bonaiti-Pellié $C$, Thomas G: BRCA1 sequence variations in 160 individuals referred to a breast/ ovarian family cancer clinic. Am J Hum Genet 1997, 60(5):1021-30, Institut Curie Breast Cancer Group.

19. Håkansson S, Johannsson O, Johansson U, Sellberg G, Loman N, Gerdes AM, Holmberg E, Dahl N, Pandis N, Kristoffersson U, Olsson H, Borg A: Moderate frequency of BRCA1 and BRCA2 germ-line mutations in Scandinavian familial breast cancer. Am J Hum Genet 1997, 60(5):1068-78.

20. Vehmanen P, Friedman LS, Eerola H, McClure M, Ward B, Sarantaus L, Kainu T, Syrjäkoski K, Pyrhönen S, Kallioniemi OP, Muhonen T, Luce M, Frank TS, Nevanlinna H: Low proportion of BRCA1 and BRCA2 mutations in Finnish breast cancer families: evidence for additional susceptibility genes. Hum Mol Genet 1997, 6(13):2309-15.

21. Goelen G, Teugels E, Bonduelle M, Neyns B, De Grève J: High frequency of BRCA1/2 germline mutations in 42 Belgian families with a small number of symptomatic subjects. J Med Genet 1999, 36(4):304-8.

22. De Grève J, Sermijn E, De Brakeleer $S$, Ren Z, Teugels E: Hereditary breast cancer: from bench to bedside. Curr Opin Oncol 2008, 20(6):605-13.

23. de la Hoya M, Osorio A, Godino J, Sulleiro S, Tosar A, Perez-Segura P, Fernandez C, Rodríguez R, Díaz-Rubio E, Benítez J, Devilee P, Caldés T: Association between BRCA1 and BRCA2 mutations and cancer phenotype in Spanish breast/ovarian cancer families: implications for genetic testing. Int J Cancer 2002, 97(4):466-71.

24. Wagner TM, Möslinger RA, Muhr D, Langbauer G, Hirtenlehner $K$, Concin $H$, Doeller W, Haid A, Lang AH, Mayer P, Ropp E, Kubista E, Amirimani B, Helbich T, Becherer A, Scheiner O, Breiteneder H, Borg A, Devilee P, Oefner $\mathrm{P}$, Zielinski C: BRCA1-related breast cancer in Austrian breast and ovarian cancer families: specific BRCA1 mutations and pathological characteristics. Int J Cancer 1998, 77(3):354-60.

25. Giannini G, Capalbo C, Ristori E, Ricevuto E, Sidoni T, Buffone A, Cortesi E, Marchetti P, Scambia G, Tomao S, Rinaldi C, Zani M, Ferraro S, Frati L, Screpanti I, Gulino A: Novel BRCA1 and BRCA2 germline mutations and assessment of mutation spectrum and prevalence in Italian breast and/ or ovarian cancer families. Breast Cancer Res Treat 2006, 100(1):83-91.

26. Capalbo C, Ricevuto E, Vestri A, Ristori E, Sidoni T, Buffone O, Adamo B, Cortesi E, Marchetti P, Scambia G, Tomao S, Rinaldi C, Zani M, Ferraro S, Frati L, Screpanti I, Gulino A, Giannini G: BRCA1 and BRCA2 genetic testing in Italian breast and/or ovarian cancer families: mutation spectrum and prevalence and analysis of mutation prediction models. Ann Oncol 2006, 17(Suppl 7):34-40, vii.

27. Ottini L, Rizzolo P, Zanna I, Falchetti M, Masala G, Ceccarelli K, Vezzosi V, Gulino A, Giannini G, Bianchi S, Sera F, Palli D: BRCA1/BRCA2 mutation status and clinical-pathologic features of 108 male breast cancer cases from Tuscany: a population-based study in central Italy. Breast Cancer Res Treat 2009, 116(3):577-86

28. Stuppia L, Di Fulvio P, Aceto G, Pintor S, Veschi S, Gatta V, Colosimo A, Cianchetti E, Cama A, Mariani-Costantini R, Battista P, Palka G: BRCA1 and BRCA2 mutations in breast/ovarian cancer patients from central Italy. Hum Mutat 2003, 22(2):178-9.

29. Ottini L, D'Amico C, Noviello C, Lauro S, Lalle M, Fornarini G, Colantuoni OA, Pizzi C, Cortesi E, Carlini S, Guadagni F, Bianco AR, Frati L, Contegiacomo A, Mariani-Costantini R: BRCA1 and BRCA2 mutations in central and southern Italian patients. Breast Cancer Res 2000, 2(4):307-10.

30. Novaković S, Stegel V: Rapid detection of most frequent Slovenian germline mutations in BRCA1 gene using real-time PCR and melting curve analysis. Radiol Oncol 2005, 39:147-152.

31. Krajc M, De Grève J, Goelen $G$, Teugels E: BRCA2 founder mutation in Slovenian breast cancer families. Eur J Hum Genet 2002, 10(12):879-82

32. Human Genome Variation Society internet web site: [http://www.hgvs.org/ mutnomen/].

33. Breast Cancer Information Core internet web site: [http://research.nhgri.nih. gov/bic/].

34. Ramus SJ, Harrington PA, Pye C, DiCioccio RA, Cox MJ, GarlinghouseJones K, Oakley-Girvan I, Jacobs IJ, Hardy RM, Whittemore AS, Ponder BA,
Piver MS, Pharoah PD, Gayther SA: Contribution of BRCA1 and BRCA2 mutations to inherited ovarian cancer. Hum Mutat 2007, 28(12):1207-15.

35. Ramus SJ, Gayther SA: The contribution of BRCA1 and BRCA2 to ovarian cancer. Mol Oncol 2009, 3(2):138-50.

36. Song H, Ramus SJ, Tyrer J, Bolton KL, Gentry-Maharaj A, Wozniak E, AntonCulver H, Chang-Claude J, Cramer DW, DiCioccio R, Dörk T, Goode EL, Goodman MT, Schildkraut JM, Sellers T, Baglietto L, Beckmann MW, Beesley J, Blaakaer J, Carney ME, Chanock S, Chen Z, Cunningham JM, Dicks E, Doherty JA, Dürst M, Ekici AB, Fenstermacher D, Fridley BL, Giles, et al: A genome-wide association study identifies a new ovarian cancer susceptibility locus on 9p22.2. Nat Genet 2009, 41(9):996-1000.

37. De Brakeleer S, De Grève J, Loris R, Janin N, Lissens W, Sermijn E, Teugels E: Cancer predisposing missense and protein truncating BARD1 mutations in non-BRCA1 or BRCA2 breast cancer families. Hum Mutat 2010, 31(3): E1175-85.

38. Besic N, Cernivc B, de Grève J, Lokar K, Krajc M, Novakovic S, Zgajnar J, Teugels E: BRCA2 gene mutations in Slovenian male breast cancer patients. Genet Test 2008, 12(2):203-9.

39. Krajc M, Teugels E, Zgajnar J, Goelen G, Besic N, Novakovic S, Hocevar M, De Grève J: Five recurrent BRCA1/2 mutations are responsible for cancer predisposition in the majority of Slovenian breast cancer families. BMC Med Genet 2008, 10(9):83-90.

40. Santarosa M, Dolcetti R, Magri MD, Crivellari D, Tibiletti MG, Gallo A, Tumolo S, Della Puppa L, Furlan D, Boiocchi M, Viel A: BRCA1 and BRCA2 genes: role in hereditary breast and ovarian cancer in Italy. Int J Cancer 1999, 83(1):5-9.

41. Miolo G, Puppa LD, Santarosa M, De Giacomi C, Veronesi A, Bidoli E, Tibiletti MG, Viel A, Dolcetti R: Phenotypic features and genetic characterization of male breast cancer families: identification of two recurrent BRCA2 mutations in north-east of Italy. BMC Cancer 2006, 9:6:156.

42. Latif A, McBurney HJ, Roberts SA, Lalloo F, Howell A, Evans DG, Newman WG: Breast cancer susceptibility variants alter risk in familial ovarian cancer. Fam Cancer 2010, Published online First.

43. Loizidou MA, Cariolou MA, Neuhausen SL, Newbold RF, Bashiardes E, Marcou Y, Michael T, Daniel M, Kakouri E, Papadopoulos P, Malas S, Hadjisavvas A, Kyriacou K: Genetic variation in genes interacting with BRCA1/2 and risk of breast cancer in the Cypriot population. Breast Cancer Res Treat 2010, 121(1):147-56.

44. Palanca Suela S, Esteban Cardeñosa E, Barragán González E, Oltra Soler S, de Juan Jiménez I, Chirivella González I, Segura Huerta A, Guillén Ponce C, Martínez de Dueñas E, Bolufer Gilabert P: Identification of a novel BRCA1 large genomic rearrangement in a Spanish breast/ovarian cancer family. Breast Cancer Res Treat 2008, 112(1):63-7.

45. Vasickova P, Machackova E, Lukesova M, Damborsky J, Horky O, Pavlu H, Kuklova J, Kosinova V, Navratilova M, Foretova L: High occurrence of BRCA1 intragenic rearrangements in hereditary breast and ovarian cancer syndrome in the Czech Republic. BMC Med Genet 2007, 11:8:32.

46. Hartmann C, John AL, Klaes R, Hofmann W, Bielen R, Koehler R, Janssen B, Bartram CR, Arnold N, Zschocke J: Large BRCA1 gene deletions are found in $3 \%$ of German high-risk breast cancer families. Hum Mutat 2004, 24(6):534.

47. Konecny M, Vizvaryova M, Weismanova E, llencikova D, Mlkva I, Weismann P, Machackova G, Kausitz J: The spectrum and incidence of BRCA1 pathogenic mutations in Slovak breast/ovarian cancer families. Neoplasma 2007, 54(2):137-42.

48. Risch HA, McLaughlin JR, Cole DE, Rosen B, Bradley L, Fan I, Tang J, Li S, Zhang S, Shaw PA, Narod SA: Population BRCA1 and BRCA2 mutation frequencies and cancer penetrances: a kin-cohort study in Ontario, Canada. J Natl Cancer Inst 2006, 98(23):1694-706.

\section{Pre-publication history}

The pre-publication history for this paper can be accessed here: http://www.biomedcentral.com/1471-2350/12/9/prepub

doi:10.1186/1471-2350-12-9

Cite this article as: Stegel et al:: The occurrence of germline BRCA1 and $B R C A 2$ sequence alterations in Slovenian population. BMC Medical Genetics 2011 12:9. 